Agencies fear global crises will lose out to tsunami donations

\section{Declan Butler}

The huge outpouring of donations to the tsunami relief effort is raising concerns that the disaster might soak up funds badly needed for other humanitarian crises.

Last week the medical aid group Médecins Sans Frontières announced that it now has enough money — $€ 41$ million (US\$54 million) - for the first phase of its tsunami relief operations, and so began encouraging people to donate to its general fund instead. This money provides aid to places such as war-torn Sudan.

Tony Blair, the UK prime minister, also expressed concern last week that tsunami aid could detract from other pressing development needs. He pointed out that there was a disaster comparable to a "preventable tsunami every week in Africa", where 10,000 people die daily from AIDS and malaria alone. Blair hopes to persuade the G8 nations to approve an aid package worth half-atrillion dollars to address such issues in developing countries.

Governments have so far pledged more than US $\$ 3.4$ billion to the tsunami effort, and as Nature went to press, donors were meeting with the United Nations to firm up the figures. In the case of some pledges, including those of the United States and Japan, the hundreds of millions promised come mainly from existing budgets for development aid. "Unless there is a supplemental appropriation, then the dollars pledged will definitely have to come out of current budgets and thus will compete with other needs," says Enriqueta Bond, president of the US Burroughs Wellcome Fund.

"There is reason for concern. The tsunami will decrease the probability of major new investments in global disease control in 2005," adds Allan Schapira, policy coordinator for the World Health Organization's branch of Roll Back Malaria, a UN-led partnership.

Despite the massive loss of life, the tsunami's impact on the economies of the countries affected will be relatively modest, as ports and other major economic centres survived largely unscathed, according to US investment bank Morgan Stanley.

"While everyone opens up their coffers for these disasters, the ongoing toll from malaria, AIDS and tuberculosis is much larger than these one-time events," says Bond. "We would do more good to invest in prevention and good publichealth measures such as clean water."
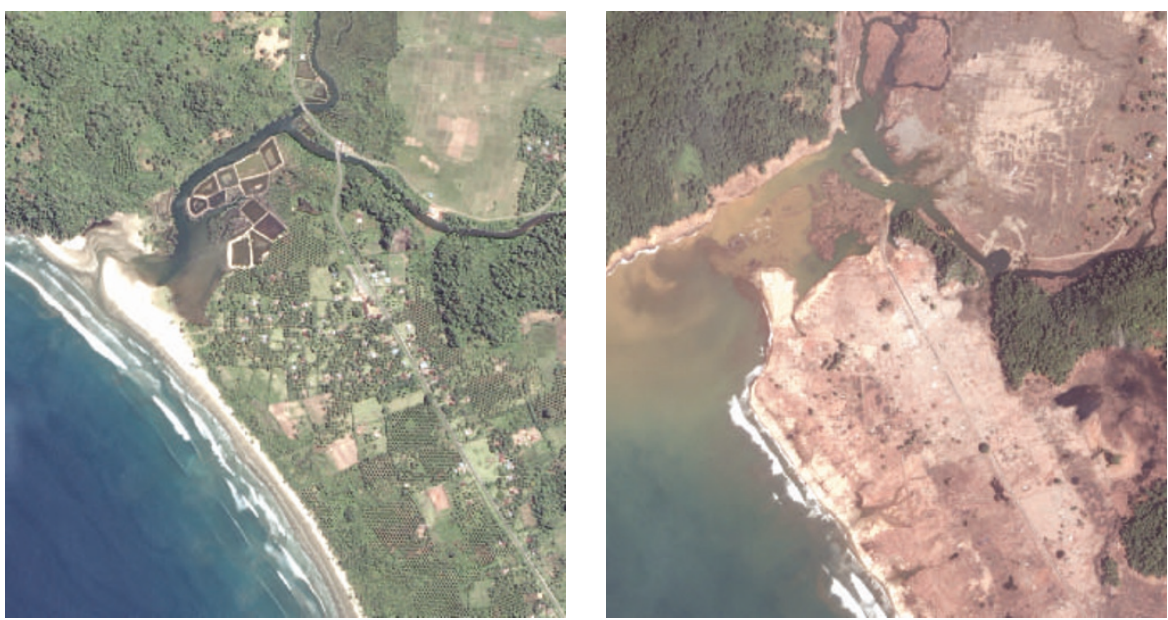

Before and after: the Asian tsunami has done untold damage to the region's environment.

\title{
Scientists seek action to fix Asia's ravaged ecosystems
}

Helen Pearson

Repairing the ecosystems damaged by the Asian tsunami should be a priority, say environmental organizations, if the longterm livelihood of devastated communities is to be secured.

They are urging the international community to ensure that marine parks are maintained, some communities are shifted inland, and defensive buffer zones of mangrove are planted against future erosion and typhoons.

Although emergency help to survivors clearly remains the main concern, environmental groups are already counting the wider cost, including eroded coastlines and saltwater pollution of fresh water and farmlands. Some coral reefs, seagrass beds and mangrove swamps, which are vital feeding and breeding grounds for fish and other ocean life, are thought to have been uprooted or smothered by sand and debris.

Without efforts to repair these ecosystems, researchers say that there could be serious, long-term consequences for the communities that rely on the coast and ocean for food, fuel and storm protection. "It'll be critical to ensure that they are re-established as quickly as possible," says Faizal Parish, a wetlands researcher who directs the Global Environment Centre in Selangor, Malaysia.

Environmental organizations say that the first priority is to document the amount and types of destruction wrought by the waves. Some have already launched preliminary surveys with satellite images and divers. And the United Nations Environment Programme announced in late December that it would initially commit US\$1 million to an environmental assessment.

But working out exactly what has been lost and its rate of recovery will be difficult. For some regions there is no information about its previous condition. And some key research labs that could monitor progress have been damaged. At Sri Lanka's main aquatic research centre, the National Aquatic Resources Research and Development Agency near Colombo, flooded instruments and a ruined research vessel will delay efforts to resume studies, says its director-general Sepalika Jayamanne.

Environmental scientists say that preexisting damage to coastlines and marine ecosystems from settlements, over-fishing, climate change and pollution worsened the impact of the tsunami and have lessened the ability of marine ecosystems to bounce back. "It's stacking one stress on top of another," says Jerker Tamelander, who coordinates the World Conservation Union's marine programme in Colombo.

In one preliminary study, Parish and his colleagues analysed satellite images of Aceh province in Sumatra, one of the worst hit regions, before and after the tsunami. They say that destruction was far worse where protective mangrove swamps had been replaced by fish farms and settlements.

To avoid repeating these mistakes, Parish and other researchers say it is vital to consider conservation priorities from the start of reconstruction.

The catastrophe should also serve as a wake-up call to other regions of the globe: areas such as those around the Pacific Ocean, where environmental damage may also have weakened natural defences against earthquakes and tsunamis, says Ian Dutton, who heads the Indonesia programme for the Nature Conservancy, an environmental group headquartered in Arlington, Virginia. "It's a chance for the world to take stock of how we're increasing our vulnerability to disasters." 